\title{
Sex, age, molt strategy, and migration distance explain the phenology of songbirds at a stopover along the East Asian flyway
}

\author{
Jonas Wobker ${ }^{1} \cdot$ Wieland Heim ${ }^{2}$ (D) Heiko Schmaljohann ${ }^{3,4}$ \\ Received: 10 August 2020 / Revised: 16 December 2020 / Accepted: 21 December 2020 / Published online: 16 January 2021 \\ (C) The Author(s) 2020
}

\begin{abstract}
Sex- and age-specific differences in the timing of migration are widespread among animals. In birds, common patterns are protandry, the earlier arrival of males in spring, and age-differential migration during autumn. However, knowledge of these differences stems mainly from the Palearctic-African and Nearctic-Neotropical flyways, while detailed information about the phenology of migrant birds from the East Asian flyway is far scarcer. To help fill parts of this gap, we analyzed how migration distance, sex, age, and molt strategy affect the spring and autumn phenologies of 36 migrant songbirds (altogether 18,427 individuals) at a stopover site in the Russian Far East. Sex-differential migration was more pronounced in spring than in autumn, with half of the studied species (6 out of 12) showing a protandrous migration pattern. Age-differences in migration were rare in spring but found in nearly half of the studied species (11 out of 25) in autumn. These age effects were associated with the birds' molt strategy and the mean latitudinal distances from the assumed breeding area to the study site. Adults performing a complete molt before the onset of autumn migration passed the study site later than first-year birds undergoing only a partial molt. This pattern, however, reversed with increasing migration distance to the study site. These sex-, age-, and molt-specific migration patterns agree with those found along other flyways and seem to be common features of land bird migration strategies.
\end{abstract}

\section{Significance statement}

The timing of animal migration is shaped by the availability of resources and the organization of annual cycles. In migrant birds, sex- and age-differential migration is a common phenomenon. For the rarely studied East Asian flyway, we show for the first time and based on a large set of migrant songbirds that earlier migration of males is a common pattern there in spring. Further, the timing and extent of molt explained age-differential migration during autumn. Adults molting their complete plumage at the breeding area before migration showed delayed phenology in comparison to first-year birds, which perform only a partial molt. This pattern, however, reversed with increasing migration distance to the study site. Since our results agree with the general patterns from the other migration flyways, similar drivers for differential migration may act across different flyway systems, provoking a similar evolutionary response.

Keywords Protandry $\cdot$ Sex $\cdot$ Age $\cdot$ Differential migration $\cdot$ Songbird $\cdot$ East Asian flyway

Jonas Wobker and Wieland Heim contributed equally to this work.

Communicated by W. Wiltschko

Wieland Heim

wieland.heim@uni-muenster.de

1 Department of Conservation Biology, Georg-August-Universität Göttingen, Göttingen, Germany

2 Institute of Landscape Ecology, University of Münster, Münster, Germany

3 Institute for Biology und Environmental Sciences (IBU), Carl von Ossietzky University of Oldenburg, Oldenburg, Germany

4 Institute of Avian Research, Wilhelmshaven, Germany

\section{Introduction}

The annual migrations of billions of animals have evolved to allow sexual partners to meet and mate where favorable environmental conditions prevail in order to successfully raise their offspring (Milner-Gulland et al. 2011; Dingle 2014). Despite the diversity of taxa and migration strategies in animals, a common phenomenon is a sex-specific timing of arrival (Morbey and Ydenberg 2001). When males arrive at the migratory destination before females, this is termed protandry, whereas the earlier arrival of females is called protogyny. Regardless of which sex arrives first, birds use three non- 
mutually exclusive proximate mechanisms (among others) to arrive earlier than others: (1) starting migration earlier, (2) traveling faster, or (3) migrating a shorter distance (Morbey and Ydenberg 2001; Coppack and Pulido 2009; Schmaljohann et al. 2016; Woodworth et al. 2016; Briedis et al. 2019; Schmaljohann 2019).

Protandry is a more common pattern during spring migration and arrival at the breeding area (Spina et al. 1994; Hüppop and Hüppop 2004; Rubolini et al. 2004; Tøttrup and Thorup 2008; Briedis et al. 2019) than protogyny (Reynolds et al. 1986). Two hypotheses are used to explain the ultimate causes of protandry in birds, namely the mate opportunity hypothesis and the rank advantage hypothesis (Morbey and Ydenberg 2001; Kokko et al. 2006). The former states that selection is acting "on males to arrive earlier than females to maximise their mating opportunity" (Morbey and Ydenberg 2001), while the latter suggests that selection is acting on the territorial sex to advance their arrival in comparison to competitors. However, when acting alone, the rank advantage hypothesis consistently failed to yield protandry in a theoretical study (Kokko et al. 2006).

In songbirds, protogyny occurs frequently during autumn migration and at wintering ground arrival (Hüppop and Hüppop 2004; Mills 2005; Lehikoinen et al. 2017; Briedis et al. 2019). Potentially, males stay longer than females at the breeding area to defend their territories and/or to prospect new potential breeding sites (Coppack and Pulido 2009; Lehikoinen et al. 2017). Also, females may migrate earlier and winter further away from the breeding area than males in order to avoid competition with males, resulting in latitudinal segregation of sexes during winter (Gauthreaux 1982). Protandrous migration is common in autumn where females are more strongly involved in breeding and chick-rearing than males (Cramp 1993; Newton 2008; Buchmann et al. 2009; Lehikoinen et al. 2017; de Zwaan et al. 2019).

In addition to sex-differential migration and arrival, Darwin (1874) and Gätke (1879) already described that older individuals usually migrate ahead of younger individuals ("age-differential migration"). Older birds are generally thought to be more efficient foragers (Gochfeld and Burger 1984; Ellegren 1991; Wunderle 1991; Zhang et al. 2015a), to be socially superior to younger birds (Gauthreaux 1978; but see Moore et al. 2003), and to be more selective regarding environmental conditions for migratory flights (Mitchell et al. 2012; Mitchell et al. 2015). Therefore, older individuals would be expected to migrate faster (Ellegren 1990; Rguibi-Idrissi et al. 2003; HallKarlsson and Fransson 2008; McKinnon et al. 2014; Sergio et al. 2014; Crysler et al. 2016), but many studies found refuting evidence (Ellegren 1991; Jones et al. 2002; Seewagen et al. 2013; Smolinsky et al. 2013; Deppe et al. 2015; Smetzer et al. 2017; McCabe and Guglielmo 2019). Still, it might be more advantageous for younger birds to forego the costs of fast migration and competition involved with arriving early at the breeding area or wintering ground and, thereby, to arrive later than their older counterparts (Kokko 1999; Stewart et al. 2002; McKinnon et al. 2014).

This general age-differential migration pattern is affected by species-specific molt strategies (Benson and Winker 2001; Carlisle et al. 2005; Kiat and Izhaki 2016; Kiat et al. 2019). For example, in birds that undergo molt in summer (hereafter "summer molters"), the first calendar-year birds perform only a partial molt, allowing them to start autumn migration prior to adults, which go through a complete molt after breeding (Kiat and Izhaki 2016). In birds that undergo molt in winter (hereafter "winter molters"), adults usually migrate ahead of second calendar-year birds during spring migration (Kiat and Izhaki 2016).

Besides sex, age, and molt strategy, migration distance additionally affects migration phenology: species that overwinter closer to the breeding area generally arrive earlier in spring and later in autumn than species that winter further away (Jenni and Kéry 2003; van Buskirk et al. 2009; Hüppop and Hüppop 2011; Schmaljohann 2019). On the other hand, species migrating different distances experience different selection pressures in terms of time, energy, and safety during migration (Alerstam and Lindström 1990; Lok et al. 2015). As such, we observe specific behavioral, physiological, and morphological adaptations that minimize time and energy spent on and mortality risk during migration. With an increase in migration distance, the corresponding adaptations result in an increased migration speed (Schmaljohann 2019). How age differences in molt strategies (see above) and potentially migration speed are connected with species' specific migration distances, is so far unknown for the East Asian flyway. For summer molters, we expect that the age effect diminishes with increasing migration distance, since adult birds, which can migrate at faster speeds (see above), eventually catch up with the first-year birds during autumn migration (Kiat and Izhaki 2016).

Our knowledge on migration phenology is strongly biased towards the Palearctic-African and Nearctic-Neotropical flyways (Spina et al. 1994; Woodrey and Chandler 1997; Cristol et al. 1999; Morbey and Ydenberg 2001; Coppack and Pulido 2009; Yosef and Wineman 2010; Schmaljohann et al. 2016; Schmaljohann 2019). While these flyways are characterized by major ecological barriers (e.g., the Mediterranean Sea, the Sahara Desert, and the Gulf of Mexico), the East Asian flyway is less interrupted by such (Heim et al. 2020). As the presence/ absence of ecological barriers shapes migratory traits in birds (Corman et al. 2014; Müller et al. 2018), such flyway-specific differences might affect the overall migration pattern. To the best of our knowledge, only single-species studies have, hitherto, detailed incidents of sex- and age-differential migration at stopover sites in China, Korea, and Russia (Wang et al. 2006; Nam et al. 2011; Averin 2012; Bozó and Heim 2016; Maslovsky et al. 2018; Bozó et al. 2019). 
Therefore, we analyzed patterns of migration phenology for a large set of East Asian songbird species at a migratory stopover site. First, we described the phenology of migrant songbirds at a stopover site in the Russian Far East and linked the interspecific variation to approximated migration distance. Based on work from other flyways (Jenni and Kéry 2003; Van Buskirk et al. 2009; Hüppop and Hüppop 2011), we expected long-distance migrants to arrive later in spring and earlier in autumn. Second, we investigated whether sex, age, and/or molt strategy could explain the observed intra- and interspecific variation in phenology. Following ecological and evolutionary theory (Kokko 1999; Stewart et al. 2002), we expected protandrous migration and earlier arrival of adults in spring. For autumn, we expected that for summer molters the firstyear birds would precede the adults, whereas in winter molters we expected the adults to migrate earlier than first-year birds.

\section{Material and methods}

\section{Study site and fieldwork}

Birds were caught at the Muraviovka Park for Sustainable Land Use in the Russian Far East as part of the Amur Bird Project in the years 2011 to 2017 . The study site (49 $55^{\prime} 8.3^{\prime \prime} \mathrm{N} 127^{\circ} 40^{\prime}$ $\left.19.9^{\prime \prime} \mathrm{E}\right)$ is located along the middle stream of the river Amur, $60 \mathrm{~km}$ southeast of the city of Blagoveshchensk. Muraviovka Park plays an important role as a breeding and stopover habitat for diverse avifauna (Heim and Smirenski 2017). Since 2011, birds have been trapped in a standardized way with mist-nets in a variety of habitats (Heim et al. 2012, 2018; Heim and Smirenski 2013). For our analyses, we used data from four spring (2012-2017) and five autumn seasons (2011-2017). Birds were identified, sexed, and aged following Svensson (1992), Brazil (2009), and Demongin (2016). Information on molt strategies of the studied species was additionally obtained from Byers et al. (1995), Clement and Rose (2015), and Shirihai and Svensson (2018). It was not possible to record data blind because our study involved individually marked animals in the field.

\section{Migration phenology}

We defined the spring season as lasting from 2 March to 15 June and the autumn season from 1 August to 16 November. These times encompass the main migration periods as demonstrated by (1) the typical bell-shaped frequency distribution of captures over the seasons (Online Resource 1A) and (2) the exceptionally low numbers of actively migrating songbirds caught between the seasons in summer (WH, unpublished data). Some very early (before March) or late (after mid-November) migrating individuals might have been missed, and single individuals of some species might overwinter at the study site, but their impact on our general results is assumed to be negligible.

\section{Data selection}

We only considered first captures; all recaptures were excluded. Birds captured using tape lure were not included to avoid potential sex biases (Schekkerman 1999; Lecoq and Catry 2003). To minimize the effect of local breeders and uncommon species in our analyses, we excluded all species that regularly breed at the study site (with $>3$ pairs) and that are rarely caught at the study site ( $<40$ individuals in all years). If the sample size for a given species was $<20$ individuals in one season, the data for that season were not considered. The resulting dataset included 28 species for spring and 36 for autumn migration (Table 1).

\section{Approximated migration distance and latitudes of seasonal distribution}

We used the difference in degrees between mean breeding and wintering latitudes of each species to approximate speciesspecific migration distances. A species' mean breeding latitude and wintering latitude were calculated as the average of the northern and southern boundary of its breeding and wintering range in East Asia (Online Resource 1B). Data on the seasonal distribution were derived from BirdLife International range maps (BirdLife International and Handbook of the Birds of the World 2017) (Online Resource 1B). In 26 species, the southern limit of the breeding range lay south of our study area. Therefore, we defined the southern latitude of the breeding area as the latitude of the study area $\left(49^{\circ} \mathrm{N}\right)$ in order to consider only the part of the breeding area relevant for the populations migrating through our study area (assuming an autumn migration from north to south and vice versa in spring). The same applied accordingly to the northern border of the wintering area. If this was north of our study area, we defined the northern latitude of the wintering area as the latitude of the study area $\left(49^{\circ} \mathrm{N}\right)$. Arctic Redpoll Acanthis hornemanni and Common Redpoll A. flammea were excluded from this analysis because BirdLife International and Handbook of the Birds of the World (2018) consider both as one species and, therefore, do not provide taxon-specific distribution areas. Furthermore, we could not approximate the migration distances for Eurasian Jay Garrulus glandarius, Coal Tit Periparus ater, Willow Tit Poecile montanus, Azure Tit Cyanistes cyanus, Great Tit Parus major, Longtailed Tit Aegithalos caudatus, and Eurasian Nuthatch Sitta europaea since no seasonal distribution range maps are provided for largely resident species by BirdLife International and Handbook of the Birds of the World (2018).

\section{Statistical analysis}

All analyses were conducted using the software $\mathrm{R}$ version 3.5.0 (R Core Team 2013). We fitted separate models for most 
Table 1 English and scientific names of all analyzed species in spring and autumn taxonomically ordered following the IOC World Bird List (v8.2) (Gill and Donsker 2008)

\begin{tabular}{|c|c|c|c|}
\hline English name & Scientific name & Spring & Autumn \\
\hline Brown Shrike & Lanius cristatus & $\mathrm{x}$ & $\mathrm{x}$ \\
\hline Eurasian Jay & Garrulus glandarius & $\mathrm{x}$ & $\mathrm{x}$ \\
\hline Coal Tit & Periparus ater & & $\mathrm{x}$ \\
\hline Willow Tit & Poecile montanus & $\mathrm{x}$ & $\mathrm{x}$ \\
\hline Azure Tit & Cyanistes cyanus & & $\mathrm{x}$ \\
\hline Great Tit & Parus major & & $\mathrm{x}$ \\
\hline Long-tailed Tit & Aegithalos caudatus & $\mathrm{x}$ & $\mathrm{x}$ \\
\hline Yellow-browed Warbler & Phylloscopus inornatus & $\mathrm{x}$ & $\mathrm{x}$ \\
\hline Pallas's Leaf Warbler & Phylloscopus proregulus & $\mathrm{x}$ & $\mathrm{x}$ \\
\hline Radde's Warbler & Phylloscopus schwarzi & $\mathrm{x}$ & $\mathrm{x}$ \\
\hline Two-barred Warbler & Phylloscopus plumbeitarsus & $\mathrm{x}$ & $\mathrm{x}$ \\
\hline Pale-legged Leaf Warbler & Phylloscopus tenellipes & $\mathrm{x}$ & $\mathrm{x}$ \\
\hline Arctic Warbler & Phylloscopus borealis & $\mathrm{x}$ & $\mathrm{x}$ \\
\hline Eurasian Nuthatch & Sitta europaea & & $\mathrm{x}$ \\
\hline Gray-backed Thrush & Turdus hortulorum & $\mathrm{x}$ & $\mathrm{x}$ \\
\hline Naumann's Thrush & Turdus naumanni & & $\mathrm{x}$ \\
\hline Dusky Thrush & Turdus eunomus & $\mathrm{x}$ & $\mathrm{x}$ \\
\hline Asian Brown Flycatcher & Muscicapa dauurica & $\mathrm{x}$ & $\mathrm{x}$ \\
\hline Rufous-tailed Robin & Larvivora sibilans & $\mathrm{x}$ & $\mathrm{x}$ \\
\hline Bluethroat & Luscinia svecica & & $\mathrm{x}$ \\
\hline Red-flanked Bluetail & Tarsiger cyanurus & $\mathrm{x}$ & $\mathrm{x}$ \\
\hline Mugimaki Flycatcher & Ficedula mugimaki & $\mathrm{x}$ & $\mathrm{x}$ \\
\hline Taiga Flycatcher & Ficedula albicilla & $\mathrm{x}$ & $\mathrm{x}$ \\
\hline Siberian Accentor & Prunella montanella & $\mathrm{x}$ & $\mathrm{x}$ \\
\hline Olive-backed Pipit & Anthus hodgsoni & $\mathrm{x}$ & $\mathrm{x}$ \\
\hline Brambling & Fringilla montifringilla & $\mathrm{x}$ & $\mathrm{x}$ \\
\hline Common Rosefinch & Carpodacus erythrinus & $\mathrm{x}$ & $\mathrm{x}$ \\
\hline Pallas's Rosefinch & Carpodacus roseus & $\mathrm{x}$ & $\mathrm{x}$ \\
\hline Common Redpoll & Acanthis flammea & $\mathrm{x}$ & $\mathrm{x}$ \\
\hline Arctic Redpoll & Acanthis hornemanni & & $\mathrm{x}$ \\
\hline Little Bunting & Emberiza pusilla & $\mathrm{x}$ & $\mathrm{x}$ \\
\hline Yellow-browed Bunting & Emberiza chrysophrys & $\mathrm{x}$ & $\mathrm{x}$ \\
\hline Rustic Bunting & Emberiza rustica & $\mathrm{x}$ & $\mathrm{x}$ \\
\hline Yellow-throated Bunting & Emberiza elegans & $\mathrm{x}$ & $\mathrm{x}$ \\
\hline Chestnut Bunting & Emberiza rutila & & $\mathrm{x}$ \\
\hline Pallas's Reed Bunting & Emberiza pallasi & $\mathrm{x}$ & $\mathrm{x}$ \\
\hline
\end{tabular}

aspects because our samples were highly unbalanced with respect to sex and age (see above), using the R-package "Ime4" (Bates et al. 2015). We did not control for phylogeny because the different molt strategies were not linked to specific genera and the variation in migration distance was comparable between genera (Table 2, Online Resource 1B).

We assessed the effect of the approximated species-specific migration distance on the between-species variation in phenology by fitting two normal linear regression models (LMs), one for spring and one for autumn. We used the median of the species-specific phenology as the dependent variable and the latitudinal difference between the breeding area and wintering ground as the explanatory variable.

We assessed the effect of sex and age on the within-species variation in phenology by fitting linear mixed models (LMMs) with the day of capture, Julian date (1 January =1), as the dependent variable, one for each species and migratory season (i.e., spring and autumn). The initial model included sex (categorical - two levels: male and female), age (categorical - two levels for spring, cy $=$ calendar-year: 2 cy and $>2$ cy; two levels for autumn: 1 cy and > 1 cy; for details see "Data selection"), and the two-way interaction between sex and age 
Table 2 Molt strategies and autumn age effects in the studied species. Significant age effects are printed in bold. Positive numbers indicate earlier migration of juveniles (first calendar-year, 1 cy); negative numbers indicate earlier migration of adults (second calendar-year and older, > $1 \mathrm{cy}$ )

\begin{tabular}{|c|c|c|c|}
\hline Species & $\begin{array}{l}\text { Time difference } \\
(1 \mathrm{cy} \text { and }>1 \mathrm{cy})\end{array}$ & Median migration date & Molt strategy of adults \\
\hline Coal Tit & -4.4 & 27.09 . & Summer complete \\
\hline Periparus ater & $(-10 / 1.1)$ & & \\
\hline Azure Tit & 2.3 & 07.10 & Summer complete \\
\hline Cyanistes cyanus & $(-8.4 / 12.8)$ & & \\
\hline Great Tit & Age-sex interaction & 01.10 & Summer complete \\
\hline Parus major & & & \\
\hline Yellow-browed Warbler & 3.2 & 07.09 . & Summer complete \\
\hline Phylloscopus inornatus & $(0.8 / 5.7)$ & & \\
\hline Two-barred Warbler & 0.5 & 28.08 . & Summer partial \\
\hline Phylloscopus plumbeitarsus & $(-5 / 5.8)$ & & Winter complete \\
\hline Arctic Warbler & -2.2 & 24.08 . & Summer complete \\
\hline Phylloscopus borealis & $(-6.1 / 1.7)$ & & \\
\hline Eurasian Nuthatch & -5.9 & 01.10 & Summer complete \\
\hline Sitta europaea & $(-11.7 /-0.3)$ & & \\
\hline Gray-backed Thrush & 1.1 & 15.09 & Summer complete \\
\hline Turdus hortulorum & $(-6.3 / 8.7)$ & & \\
\hline Naumann's Thrush & -6.0 & 01.10 & Summer complete \\
\hline Turdus naumanni & $(-9.1 /-2.9)$ & & \\
\hline Dusky Thrush & -4.7 & 24.09 . & Summer complete \\
\hline Turdus eunomus & $(-7.6 /-1.9)$ & & \\
\hline Rufous-tailed Robin & -0.5 & 09.09 . & Summer complete \\
\hline Larvivora sibilans & $(-2.8 / 1.8)$ & & \\
\hline Red-flanked Bluetail & -1.2 & 25.09 . & Summer complete \\
\hline Tarsiger cyanurus & $(-4.2 / 1.8)$ & & \\
\hline Mugimaki Flycatcher & 2.8 & 10.09 . & Summer complete \\
\hline Ficedula mugimaki & $(-0.1 / 5.8)$ & & \\
\hline Taiga Flycatcher & 5.3 & 05.09 . & Summer complete \\
\hline Ficedula albicilla & $(2.5 / 8.1)$ & & \\
\hline Siberian Accentor & 0.8 & 02.10 & Summer complete \\
\hline Prunella montanella & $(-1.5 / 3.1)$ & & \\
\hline Brambling & 0.1 & 21.09. & Summer complete \\
\hline Fringilla montifringilla & $(-1.6 / 1.6)$ & & \\
\hline Common Rosefinch & -15.2 & 08.09 & Winter complete \\
\hline Carpodacus erythrinus & $(-26.5 /-4.4)$ & & \\
\hline Common Redpoll & 0.8 & 13.10 . & Summer complete \\
\hline Acanthis flammea & $(-0.3 / 2)$ & & \\
\hline Arctic Redpoll & 1.8 & 09.11. & Summer complete \\
\hline Acanthis hornemanni & $(-2 / 5.6)$ & & \\
\hline Little Bunting & -4.7 & 21.09. & Summer complete \\
\hline Emberiza pusilla & $(-6.7 /-3.3)$ & & \\
\hline Rustic Bunting & -1.7 & 28.09 & Summer complete \\
\hline Emberiza rustica & $(-2.7 /-0.6)$ & & \\
\hline Yellow-browed Bunting & -13.3 & 01.09 . & Winter complete $^{\mathrm{a}}$ \\
\hline Emberiza chrysophrys & $(-16.3 /-10.3)$ & & \\
\hline Yellow-throated Bunting & 8.4 & 19.09. & Summer complete \\
\hline Emberiza elegans & $(4 / 12.9)$ & & \\
\hline Chestnut Bunting & -6 & 30.08 . & Molt Migration \\
\hline Emberiza rutile & $(-13.7 / 1.7)$ & & \\
\hline Pallas's Reed Bunting & -2.1 & 09.10 . & Summer complete \\
\hline Emberiza pallasi & $(-3.5 /-0.6)$ & & \\
\hline
\end{tabular}

${ }^{a}$ Our own observations suggest molt migration in some individuals 
as explanatory variables. Year was included as a random intercept. If the two-way interaction was not significant, it was removed from the final species- and season-specific model. In those species which had only a sufficiently high sample size for either sex or age (see "Data selection"), only the corresponding explanatory variable was included in the LMM. In the Red-flanked Bluetail Tarsiger cyanurus, we assessed sex and age effects in two different models for spring migration because many sexed individuals could not be aged and many aged individuals could not be sexed.

For summer molters, we assessed whether breeding latitude explained the differences in median migration date between adults and first-year birds during autumn migration, given that adults from distant breeding areas might compensate their later departure (because of molt) by migrating faster. For this purpose, we ran an LM with the difference in median migration dates of 1 cy and $>1$ cy ( $\Delta$ median migration date) as the dependent variable and mean breeding latitude as the explanatory variable.

The diagnostic residual and random effect plots of all models indicated that the data did not violate the model assumptions. Marginal and conditional $\mathrm{R}^{2}$ of all LMs are given in Online Resource 1I. To assess the uncertainty of the model estimates and model predictions, we used Bayesian methods to obtain uncertainty estimates of the model parameters. In all models, we used improper prior distributions: $\mathrm{p}(\beta) \sim 1$ for the coefficients and $\mathrm{p}(\beta) \sim 1 / \sigma$ for the variance parameters, following KornerNievergelt et al. (2015) and using the corresponding R package "blmeco." To obtain the posterior distribution, we directly simulated 5000 values from the joint posterior distribution of the model parameters using the function sim of the R package "arm" (Gelman and Hill 2016). The means of the simulated values from the joint posterior distributions of the model parameters were used as estimates, and the $2.5 \%$ and $97.5 \%$ quantiles were used as lower and upper limits of the $95 \%$ credible intervals $(\mathrm{CrI})$. We declared an effect to be significant if the corresponding 95\% CrI did not include zero or the $95 \%$ CrIs of the compared groups did not overlap (Korner-Nievergelt et al. 2015).

\section{Results}

\section{Migration phenology}

The migration phenologies varied considerably between the 28 species (5734 individuals) in spring and the 36 species $(12,693$ individuals) in autumn (Fig. 1, Online Resource 1A, C, D).

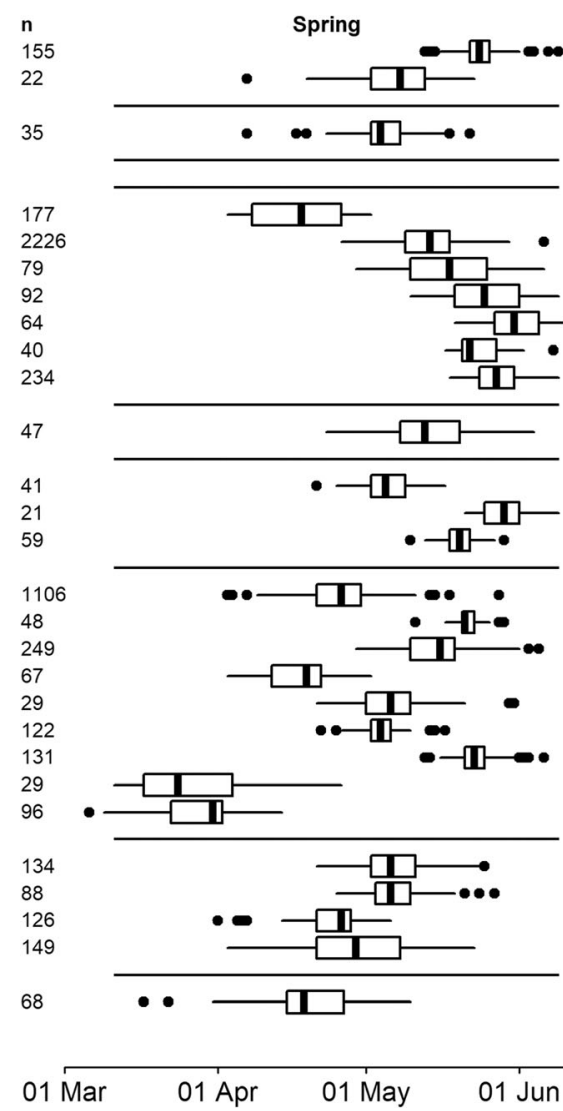

Fig. 1 Phenologies of 28 East Asian songbird species for spring migration (left) and of 36 species for autumn migration (right). Boxplots with boxes showing the 25th, 50th, and 75th quantiles and whiskers with a length of $1.5 \times$ the interquartile range. Outliers outside
Species

Brown Shrike

Eurasian Jay

Coal Tit

Willow Tit

Long-tailed Tit

Yellow-browed Warbler

Pallas's Leaf Warbler

Radde's Warble

Two-barred Warbler

Ale-legged Leaf

Eurasian Nuthatch

Grey-backed Thrush

Naumann's Thrush

Dusky Thrush

Asian Brown Flycatcher

Rufous-tailed Robin

Bluethroat

Red-flanked Bluetail

Mugimaki Flycatcher

Taiga Flycatcher

Siberian Accentor

Olive-backed Pipit

Brambling

Common Rosefinch

Pallas's Rosefinch

Common Redpoll

Aictic Redpol

Yellow-browed Bunting

Rustic Bunting

Yellow-throated Bunting

Chestnut Bunting

Pallas's Reed Bunting

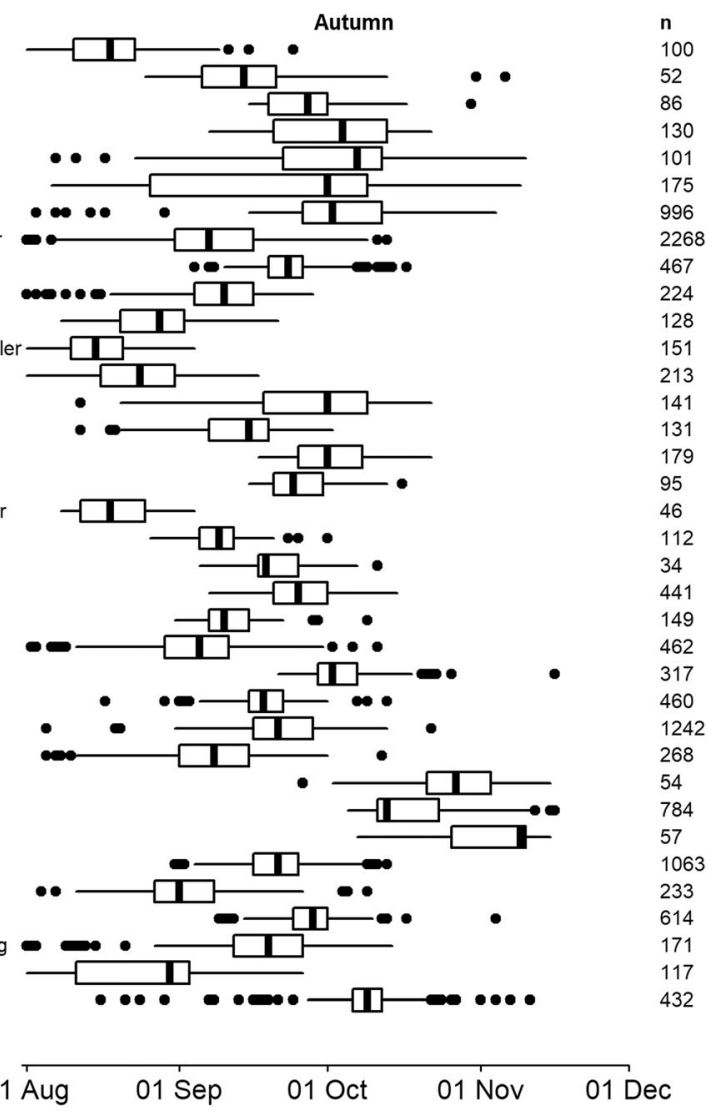

this range are shown as dots. English names are taxonomically ordered following IOC World Bird List (v8.2) (Gill and Donsker 2008); see Table 1 for scientific names. Numbers of individuals considered per species and season are displayed on either side of the figure 


\section{Approximated migration distance}

We found a significant positive effect of the approximated migration distance on the median migration date of the species in spring (LM: Estimate: 1.19, 95\%CrI: 0.72/1.65) and a significant negative effect in autumn (LM: Estimate: -1.36 , 95\% CrI: $-1.9 /-0.82$ ). This means that species migrating longer distances passed the stopover site later in spring and earlier in autumn than species migrating shorter distances, or alternatively that species migrating to higher latitudes (for breeding) migrated later in spring and earlier in autumn (Fig. 2).

\section{Sex, age, and molt effects}

In spring, males significantly preceded females in six out of twelve species (Fig. 3a, Online Resource 1E). The degree of protandry ranged between 2 and 9 days. In two out of eight species, $>2$ cy birds showed a significantly advanced arrival timing in comparison to 2 cy birds (Fig. 3b, Online Resource $1 \mathrm{E}):>2$ cy birds migrated on average 2.4 and 5 days earlier than 2 cy birds in Red-flanked Bluetails and Taiga Flycatchers Ficedula albicilla, respectively. A significant two-way interaction between sex and age was found in the Yellow-browed Bunting Emberiza chrysophrys: $>2$ cy males migrated significantly earlier than $>2$ cy females (LM: Estimate: 7.6 days, 95\% CrI: 4.6/10.3), whereas no such sex difference was found in 2 cy birds (LM: Estimate: 1.5, 95\% CrI: $-2.5 / 5.6$ ) (Online Resource 1G).

In autumn, four out of 14 species showed significant sex differences in their migration phenology (Fig. 4a, Online Resource $1 \mathrm{~F}$ ); in three of those species, females migrated earlier than males. The median differences in timing

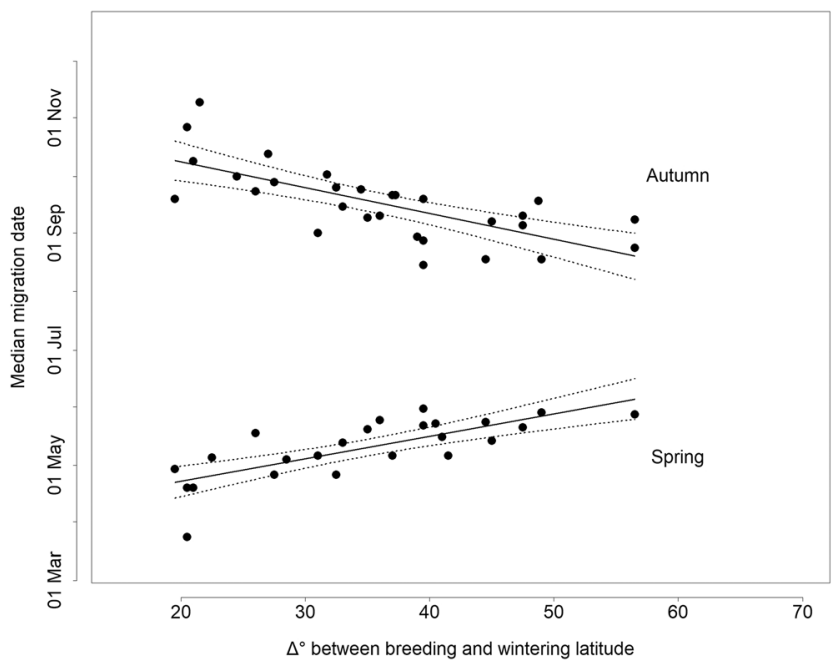

Fig. 2 Relationship between migration phenology (median migration date) at a stopover site and the migration distance $\left(\Delta^{\circ}\right.$ latitudes between species-specific mean breeding and wintering latitudes) of 24 East Asian songbird species in spring and 29 in autumn. Shown are the regression lines (solid lines) including the $95 \%$ credible intervals (dotted lines) ranged between 1.1 and 2.1 days. In one species, the Yellowthroated Bunting Emberiza elegans, males migrated ahead of females with a median difference of 6.6 days. We found significant age effects in eleven of 25 species (Table 2, Fig. 4b, Online Resource 1F). In eight of these, $>1$ cy birds migrated significantly earlier than 1 cy birds by 1.7 to 15.2 days. Six of these eight species are summer molters. We found the greatest difference in timing between the age classes in the two winter molters, the Common Rosefinch Carpodacus erythrinus (13.3 days) and Yellow-browed Bunting (15.2 days) (Table 2). In three summer molters, $>1$ cy birds migrated significantly later than 1 cy birds by 3.2 to 8.4 days (Table 2, Fig. 4). In the Great Tit Parus major, the two-way interaction between age and sex was significant, suggesting that 1 cy males migrated significantly earlier than $>1$ cy males (LM: Estimate: 12.9, 95\% CrI: 1.35/23.75); but no significant age effect was found in females (LM: Estimate: - 3.0, 95\% CrI: - 12.1/5.7) (Online Resource 1H).

In summer molters, we found a significant age-specific effect of the mean breeding latitude on the difference in median migration date of 1 cy birds and $>1$ cy birds in autumn (LM: Estimate: -0.6 , 95\%CrI: $-1.2 /-0.1$ ) (Fig. 5). This means that $>1$ cy birds migrated ahead of $1 \mathrm{cy}$ birds when originating from more northern latitudes, whereas 1 cy birds preceded $>1$ cy birds when coming from more southern latitudes.

\section{Discussion}

This study demonstrates that the approximated migration distance and/or the breeding latitude significantly affects the migration phenology of songbird species along the East Asian flyway, with shorter distances and/or lower breeding latitudes yielding early spring passage and late autumn passage (Fig. 2). Our results also provide the first evidence that protandry is a common phenomenon along this flyway in spring (Fig. 3a), whereas sex-differential migration is far less pronounced in autumn (Fig. 4a). Age-differential migration, in contrast, is more frequent in autumn than in spring (Figs. $3 b$ and $4 b$ ). For summer molters, age-differential migration in autumn is associated with the birds' median breeding latitude, with $1 \mathrm{cy}$ birds preceding $>1$ cy birds when breeding close to the study site (Fig. 5). Based on a large sample size, including many species as well as many individuals, we, therefore, show here that the general migration patterns observed along the other main migration flyways (e.g., Myers 1981; Rubolini et al. 2004; Tøttrup and Thorup 2008; Schmaljohann 2019) are also found in migrant songbirds traveling along the East Asian flyway. This suggests that similar ultimate and proximate mechanisms probably shape the migration patterns along the main migration flyways. 
a)

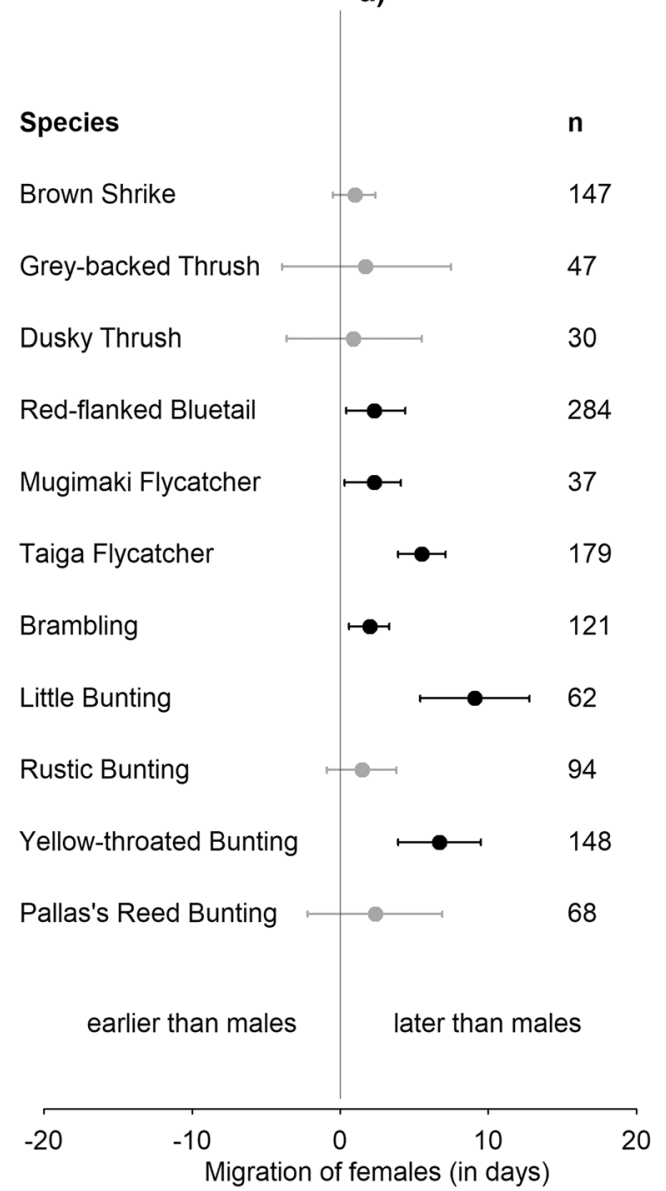

Fig. 3 Arrival date at the stopover site (with 95\% credible intervals) of a male songbirds relative to arrival date of the females and $\mathbf{b}$ older birds (> 2 cy) relative to the arrival data of young birds $(2 \mathrm{cy})$ in spring. Significant effects (credible intervals not including zero) are presented in bold. b)

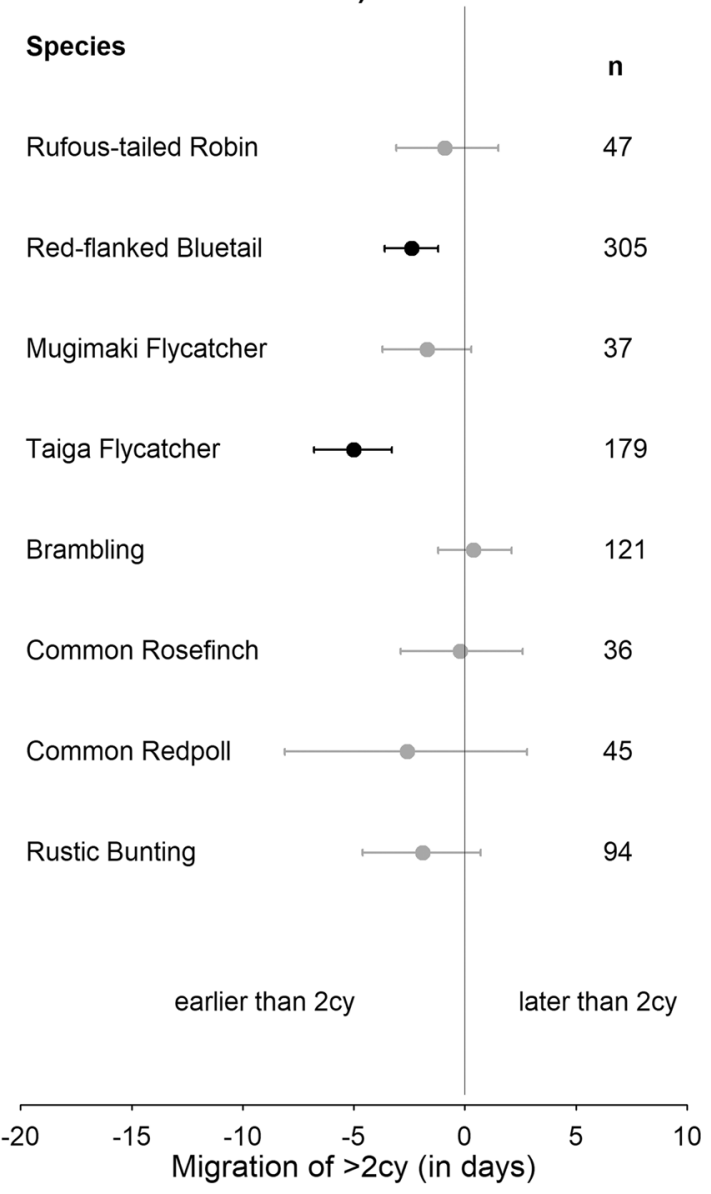

Sample sizes (n) are given on the right. Species with a significant sexage-interaction are not depicted (see Online Resource $1 \mathrm{G}$ ). cy = calendaryear

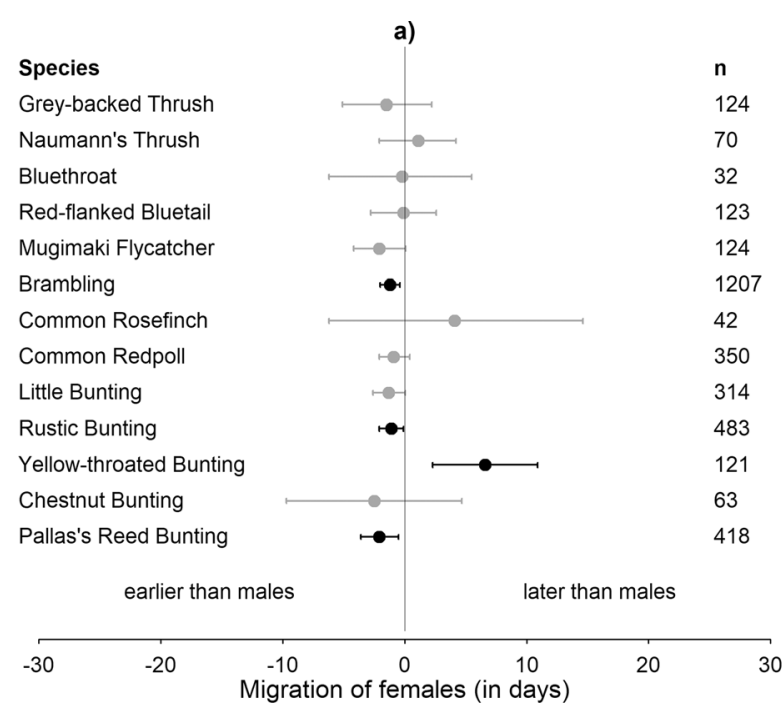

Fig. 4 Arrival date at the stopover site (with 95\% credible intervals) of a male songbirds relative to arrival date of the females and $\mathbf{b}$ older birds (> $1 \mathrm{cy}$ ) relative to the arrival data of young birds (1 cy) in autumn. Significant effects (95\% credible intervals not including zero) are presented in bold. Sample sizes (n) are given to the right. In $\mathbf{b}$ letters in

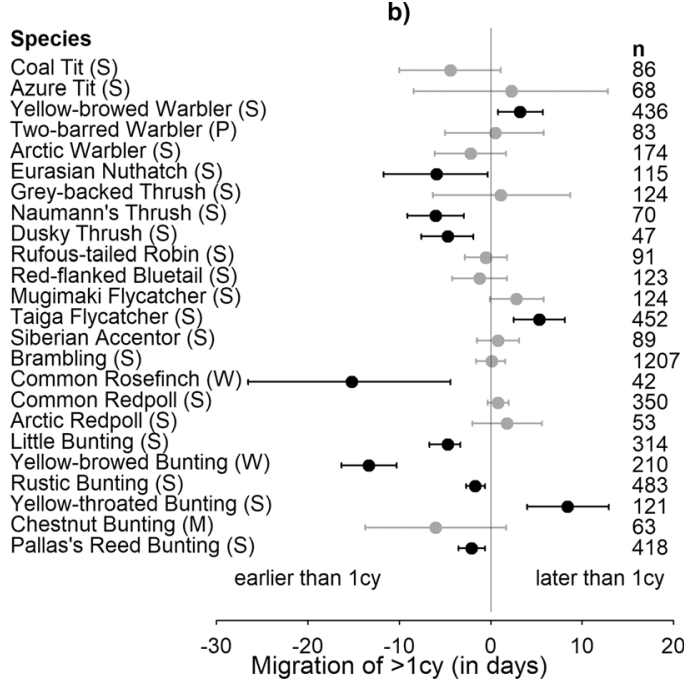

brackets indicate molt strategy (S: complete molt in summer; W: complete winter molt; P: partial summer and a complete winter molt; $\mathrm{M}$ : molt migration). Species with a significant sex-age-interaction are not depicted (see Online Resource 1H). cy = calendar-year 


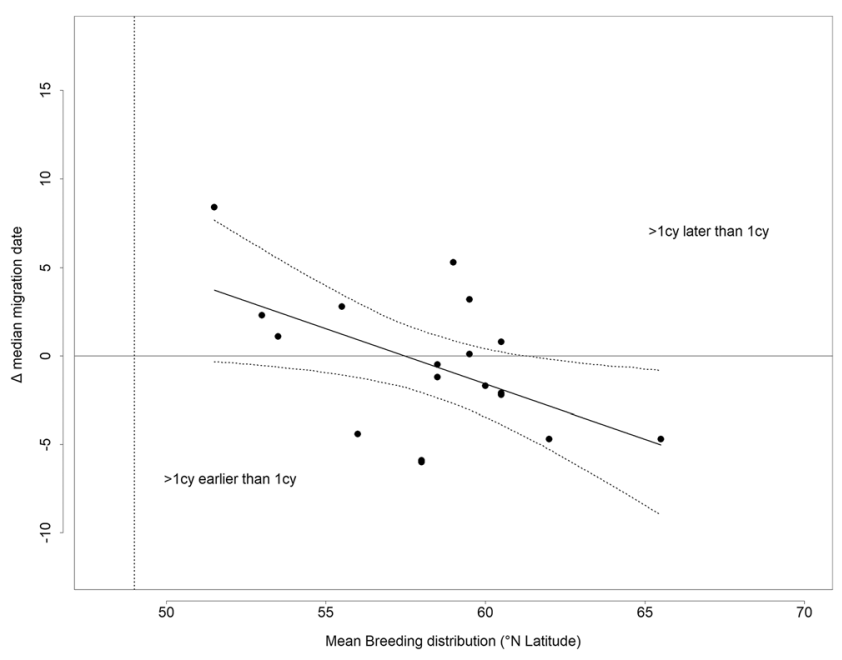

Fig. 5 Age-specific effect of median breeding distribution on the median migration date of summer molters in autumn $(n=18$ species). Depicted are differences in migration between juveniles ( $1 \mathrm{cy}$ ) and adult birds $(>1$ cy). Shown is the regression line (solid line) including the $95 \%$ credible intervals (dotted lines). Vertical dashed line indicates the latitude of the study site $\left(49^{\circ} \mathrm{N}\right)$. cy $=$ calendar-year

\section{Approximated migration distance}

We found that species migrating longer "distances" and/or breeding at higher latitudes arrive later in spring and earlier in autumn than species migrating shorter "distances" (Fig. 2), which is in line with the pattern found in eight Emberiza buntings and seven Phylloscopus warblers passing the same study site (Heim et al. 2018; Bozó et al. 2020). Since the overall pattern for the East Asian flyway is congruent with that found for various species along other flyways (Jenni and Kéry 2003; Van Buskirk et al. 2009; Hüppop and Hüppop 2011), it appears to be a global pattern that the migration phenology of long-distance migrants is seasonally framed by the phenologies of short- or medium-distance migrants (Fig. 2).

Long-distance migration has evolved as a consequence of strong seasonality, e.g., the unavailability of preferred prey or habitats due to winter snow cover in the North (Alerstam et al. 2003). In our study, the species with the longest approximated migration distances are mostly either obligate insectivores (e.g., Brown Shrike Lanius cristatus, Asian Brown Flycatcher Muscicapa dauurica) or species that breed in highly seasonal habitats (e.g., Arctic Warbler Phylloscopus borealis breeding in sub-arctic shrubs). In order to track their preferred resources, these species have to arrive late in spring and leave early in autumn (cf. Thorup et al. 2017). Furthermore, long-distance migration might evolve to escape competition (Alerstam et al. 2003), which potentially explains the pronounced variation in migration distances and timing among the morphologically similar East Asian buntings (Heim et al. 2018). In contrast to that of the long-distance migrants, the food niche of many shorter-distance migrants in our study, such as tits, Siberian Accentor Prunella montanella and finches, is relatively broad (Dement'ev and Gladkov 1954). These species might be, therefore, less dependent on the availability of arthropods by switching to a more seed- and/or fruit-rich diet earlier and later in the year (Bairlein and Gwinner 1994). This enables them to meet their food requirement when obligate insectivores would fail to do so (Bairlein and Gwinner 1994).

\section{Sex-differential migration in spring}

In spring, we found protandry in half of the studied species (Fig. 3a), in line with Nam et al. (2011) and Bozó and Heim (2016), who also reported protandry in buntings and leafwarblers migrating along the East Asian flyway. Specifically, at a Korean stopover site, the degree of protandry of Yellow-throated Buntings (7.5 days) and Yellow-browed Buntings (1.3 days) was similar to that found in our study (6.7 days and 1.5 days [but only for 2 cy birds]) (Nam et al. 2011). However, we observed that adult male Yellow-browed Buntings arrive at Muraviovka Park earlier than females by 7.4 days (Online Resource 1G).

Overall, the degree of protandry was 2 to 9 days (Fig. 3a, Table Online Resource 1E), which is comparable to that found in Europe and North America (Spina et al. 1994; Tøttrup and Thorup 2008; Cooper et al. 2009). In some studies, this degree was positively linked to sexual size dimorphism (Kissner et al. 2003), migration timing (Francis and Cooke 1986), or extrapair paternity (Coppack et al. 2006). Furthermore, Rubolini et al. (2004) found the highest degree of protandry in species with high levels of sexual dichromatism. In our study, the highest degree was observed in the Little Bunting Emberiza pusilla, a species in which males and females barely differ in coloration at all (Svensson 1992). Therefore, more studies are needed to better understand what kind of traits correlate positively with the strength of sex-differential migration along the East Asian flyway. Although protandry is probably a general and common pattern in migrant songbirds along the East Asian flyway, we found a significant pattern only in about $50 \%$ of the species examined (Fig. 3a). We argue that the occurrence of multiple populations with different migratory destinations and overlapping passage times at our study site (cf. Bozó et al. 2019) may have obscured us from finding sexdifferential migration on the species level in some cases, although protandry may exist on the population levels.

Our understanding of the underlying proximate mechanisms for protandry along the East Asian flyway was hampered by a lack of more detailed information on the migration ecology of migrant songbirds there. Although the mechanisms for sex-differential migration along the East Asian flyway remain so far unknown, we assume that protandry is proximately caused by a sex-specific onset of spring migration, possibly in combination with sex-specific differences in 
migration speed, as shown also for other flyways (Komar et al. 2005; Coppack and Pulido 2009; Schmaljohann et al. 2016; Briedis et al. 2019). Future studies should investigate these proximate mechanisms.

\section{Sex-differential migration during autumn}

In autumn, we found sex-differential migration in less than a third of the studied taxa (Fig. 4a); both protogynous (three species) and protandrous (one species) migration patterns were observed. Previously, protogynous migration was also shown for leaf warbler species migrating along the East Asian flyway (Bozó and Heim 2016), while protandrous migration was shown for Yellow-throated Buntings in Russia (Averin 2012), with young females being the latest to migrate. This is in line with our results, as the Yellow-throated Bunting was the only species showing protandry during autumn in our study (Fig. 4a).

Diverse patterns of sex-differential migration during autumn are also known from other flyways systems, though protogyny seems to be most common (e.g., Ellegren 1991; Mills 2005). Protogyny might evolve if males benefit from a late autumn departure: while adult males might stay longer to protect their breeding territories, young males might stay longer to prospect future nesting sites (Mills 2005; Lehikoinen et al. 2017). Females, on the contrary, may benefit from an early departure, allowing them to acquire their winter territories early (Mills 2005). Protandry during autumn migration is more likely to occur if breeding costs more energy for females than for males and if the females delay the onset of their summer molt (Buchmann et al. 2009) and, in turn, their autumn migration (Lehikoinen et al. 2017). Moreover, latitudinal segregation during winter could also lead to sex-differential migration (Komar et al. 2005; Ruckstuhl 2007; Coppack and Pulido 2009). These explanations might apply to East Asian migrants as well, but too little is currently known about sex differences in wintering ranges in this region. In a recent study using stable isotopes, late migrating Yellow-throated Buntings were assigned to breeding grounds further south than early migrants from an autumn stopover site on the Korean peninsula (Choi et al. 2020). However, no significant differences were observed between males and females (Choi et al. 2020).

\section{Age effects}

In spring, we observed the earlier migration of $>2$ cy birds in two species (Fig. 3b). In a third species, the Yellow-browed Bunting, an age effect was only detectable in males (Online Resource 1G). The observed general time differences in our study ( 0 to 5 days; Fig. 3b, Online Resource 1E) are similar to those shown by migrants of the Palearctic-African and Nearctic-Neotropical flyways (0 to 10 days). However, the frequency of age-differential migration was far lower than would have been expected from the other flyways (Spina et al.
1994; Stewart et al. 2002; Schmaljohann et al. 2016). That older birds precede younger birds during spring migration could be explained if we could confirm that birds improve their migratory skills from experience (Hake et al. 2003; Sergio et al. 2014). Alternatively, if there is a strong selection pressure towards early migration, phenotypically and genetically induced late migrants would selectively disappear (van de Pol and Verhulst 2006; Zhang et al. 2015b).

For autumn migration, our results demonstrate that agedifferential migration is a common pattern of migrant songbirds along the East Asian flyway (Table 2; Fig. 4b). Earlier migration of $>1$ cy birds than 1 cy birds was also shown for Siberian Rubythroats Calliope calliope migrating through the Russian Far East (Maslovsky et al. 2018). Our finding that adults migrate ahead of juveniles in winter molters (Table 2) is in general agreement with the results of age-differential migration from other flyways (Carlisle et al. 2005; Kiat and Izhaki 2016). Additionally, the range of the time differences between the age classes ( 13 to 5 days) was of the same order of magnitude as the range (11 to 26 days) found for winter molters in Israel during autumn migration (Kiat and Izhaki 2016).

In summer molters, the pattern of age-differential autumn migration was affected by approximated migration distance (Fig. 5). 1 cy birds performing only partial molt before the onset of autumn migration migrate ahead of the $>1$ cy summer molters when the species' mean breeding latitude is relatively close to the study site. However, when the species' mean breeding latitude is sufficiently north, $>1$ cy birds compensate for the delayed onset of autumn migration, probably by migrating faster than the $1 \mathrm{cy}$ birds, and show an advanced migration phenology at our study site to overtake the earlierdeparting 1 cy birds before reaching Muraviovka Park (Fig. 5). The same pattern was observed at a stopover site in Israel (Kiat and Izhaki 2016). The more efficient and hence faster autumn migration of $>1$ cy birds is probably caused by shorter stopovers (Rguibi-Idrissi et al. 2003), earlier departure at night (Schmaljohann et al. 2018) and/or higher fuel deposition rates and longer potential flight ranges (Neto et al. 2008).

In addition to the more general molt and migration strategies (cf. Kiat et al. 2019), some Chestnut Buntings Emberiza rutila disrupt autumn migration to molt during stopover (Valchuk 2003). At our study site, most of the early-arriving individuals were $>1$ cy birds in a still worn plumage, followed by 1 cy birds. A small number of completely molted $>1 \mathrm{cy}$ birds were caught late in the season after all 1 cy birds had passed. This exceptional molt strategy resulted in two waves of $>1$ cy birds encompassing the passage of the 1 cy birds. Thus, there is age-differential migration in the Chestnut Bunting, though it was not captured by our statistical analysis (Table 2, Fig. 4b).

In the Two-barred Warbler Phylloscopus plumbeitarsus, in which both adults and juveniles undergo a partial molt before the onset of autumn migration, no significant effect of age on 
the timing of migration was found (Table 2), which supports our corresponding hypothesis.

Overall, age-differential migration was found only in a small proportion of the studied species, which conflicts with studies from other flyways (Spina et al. 1994; Stewart et al. 2002). We suggest, as for the sex-differential migration, that finding an effect of age on the timing of migration within a species is hampered by multiple populations passing our study at the same time or only slightly delayed, whereby there are potentially more apparent temporal differences between age groups with increasing migration distances.

\section{Conclusion}

Most of our findings about the general migration phenology of East Asian migrant songbirds are comparable to and in line with patterns demonstrated for other flyways. This might suggest that the underlying ultimate and proximate mechanisms for the observed sex-, age-, and molt-specific migration patterns are potentially similar in all flyway systems and have, therefore, led to similar evolutionary responses.

In many aspects, however, our interpretations are hampered by the lack of detailed knowledge on the ecology of the species of the East Asian flyway. Here, we provide basic but important information about the migration patterns of migrant songbirds of this flyway, which we hope will stimulate further research in this area. A better understanding of the species' migration ecology will help enable effective conservation measures, as many of the studied taxa decline.

Acknowledgments Open Access funding enabled and organized by Projekt DEAL. The authors want to thank Sergei M. Smirenski and the staff of Muraviovka Park as well as all volunteers of the Amur Bird Project who helped to gather this dataset. Fieldwork of the Amur Bird Project was supported by donations and grants from the German Ornithologists' Society (DO-G e.V.), the Förderkreis Allgemeine Naturkunde (Biologie) e.V., the NABU RVE e.V. and ProRing e.V. We acknowledge the provision of rings by the Bird Ringing Centre of Russia. Many thanks also to Sandra Bouwhuis (Institute of Avian Research) and three anonymous reviewers for helpful comments on an earlier draft and to Celeste Brennecka (WWU Münster) for improving the language of the manuscript.

Code availability The $\mathrm{R}$ code used to analyze the data is available upon request from the authors.

Authors' contributions HS and WH designed the study, WH collected data with support from JW, JW analyzed the data supervised by HS and $\mathrm{WH}$, and all authors interpreted the results and wrote the manuscript.

Data availability All data is available upon request from the corresponding author.

\section{Compliance with ethical standards}

Conflict of interest The authors declare that they have no conflict of interest.
Ethics approval The authors confirm that all experiments were carried out under the current law for scientific bird ringing in Russia, and all necessary permissions were obtained. Approval from an ethics committee was not required, but all applicable international, national, and institutional guidelines for the use of animals were followed.

Consent for publication All authors ensure that the Publisher has the Authors' permission to publish the enclosed work.

Open Access This article is licensed under a Creative Commons Attribution 4.0 International License, which permits use, sharing, adaptation, distribution and reproduction in any medium or format, as long as you give appropriate credit to the original author(s) and the source, provide a link to the Creative Commons licence, and indicate if changes were made. The images or other third party material in this article are included in the article's Creative Commons licence, unless indicated otherwise in a credit line to the material. If material is not included in the article's Creative Commons licence and your intended use is not permitted by statutory regulation or exceeds the permitted use, you will need to obtain permission directly from the copyright holder. To view a copy of this licence, visit http://creativecommons.org/licenses/by/4.0/.

\section{References}

Alerstam T, Hedenstrom A, Akesson S (2003) Long-distance migration: evolution and determinants. Oikos 103:247-260

Alerstam T, Lindström $\AA$ (1990) Optimal bird migration: the relative importance of time, energy, and safety. In: Gwinner E (ed) Bird migration: physiology and Ecophysiology. Springer, Berlin, pp 331-351

Averin AA (2012) Migration of Cristemberiza elegans (Temminck, 1836) - yellow-throated bunting in the Jewish autonomous Oblast. In: Proceedings on the conference of ecological and biological wellbeing of the animal world. Far Eastern State Agrarian University, Blagoveshchensk, pp 174-178 [in Russian]

Bairlein F, Gwinner E (1994) Nutritional mechanisms and temporal control of migratory energy accumulation in birds. Annual Review of Nutrition 14(1):187-215

Bates D, Mächler M, Bolker B, Walker S (2015) Fitting linear mixedeffects models using lme4. J Stat Softw 67:1-48. https://doi.org/10. 18637/jss.v067.i01

Benson A-M, Winker K (2001) Timing of breeding range occupancy among high-latitude passerine migrants. Auk 118:513-519. https:// doi.org/10.2307/4089813

BirdLife International and Handbook of the Birds of the World (2018) Bird species distribution maps of the world, version 2018.1, www. datazone.birdlife.org/species/requestdis

Bozó L, Heim W (2016) Sex-specific migration of Phylloscopus warblers at a stopover site in Far Eastern Russia. Ringing Migr 31:41-46. https://doi.org/10.1080/03078698.2016.1195213

Bozó L, Heim W, Anisimov Y, Csörgő T (2019) Seasonal morphological differences indicate possible loop migration in two, but not in another four, Siberian passerines. Forktail 35:12-19

Bozó L, Csörgö T, Heim W (2020) Factors controlling the migration phenology of Siberian Phylloscopus species. J Ornithol. https:// doi.org/10.1007/s10336-020-01805-5

Brazil M (2009) Field guide to the birds of East Asia: eastern China, Taiwan, Korea, Japan and Eastern Russia. Helm field guides. Christopher Helm, London

Briedis M, Bauer S, Adamík P, Alves JA, Costa JS, Emmenegger T, Gustafsson L, Koleček J, Liechti F, Meier CM, Procházka P, Hahn S (2019) A full annual perspective on sex-biased migration 
timing in long-distance migratory birds. Proc R Soc B 286: 20182821. https://doi.org/10.1098/rspb.2018.2821

Buchmann M, Helm B, Rothery P, Flinks H (2009) Consequences of late breeding on moult and recovery rate of a long-distance migrant, the Wheatear (Oenanthe oenanthe). Vogelwarte 47:125-133

Byers C, Olsson U, Curson J (1995) Buntings and sparrows: a guide to the buntings and North American sparrows. Pica Press, East Sussex

Carlisle JD, Kaltenecker GS, Swanson DL (2005) Molt strategies and age differences in migration timing among autumn landbird migrants in southwestern Idaho. Auk 122:1070-1085. https://doi.org/10.1093/ auk/122.4.1070

Choi C-Y, Nam H-Y, Park J-G, Bing G-C (2020) Migration pattern of yellow-throated buntings revealed by isotope-based geographic assignment. Int J Geogr Inf Sci 34:504-519. https://doi.org/10.1080/ 13658816.2019.1670832

Clement P, Rose C (2015) Robins and chats. Helm Identification Guides. Bloomsbury Publishing, London

Cooper NW, Murphy MT, Redmond LJ (2009) Age- and sex-dependent spring arrival dates of eastern kingbirds. J Field Ornithol 80:35-41

Coppack T, Pulido F (2009) Proximate control and adaptive potential of protandrous migration in birds. Integr Comp Biol 49:493-506. https://doi.org/10.1093/icb/icp029

Coppack T, Tøttrup AP, Spottiswoode C (2006) Degree of protandry reflects level of extrapair paternity in migratory songbirds. J Ornithol 147:260-265. https://doi.org/10.1007/s10336-006-0067-3

Corman A-M, Bairlein F, Schmaljohann H (2014) The nature of the migration route shapes physiological traits and aerodynamic properties in a migratory songbird. Behav Ecol Sociobiol 68:391-402. https://doi.org/10.1007/s00265-013-1653-z

Cramp S (ed) (1993) Handbook of the birds of Europe, the Middle East and North Africa: the birds of the Western Palearctic, reprinted (with corrections). Oxford University Press, Oxford

Cristol DA, Baker MB, Carbone C (1999) Differential migration revisited. In: Nolan V, Ketterson ED, Thompson CF (eds) Current ornithology. Springer, Boston, pp 33-88

Crysler ZJ, Ronconi RA, Taylor PD (2016) Differential fall migratory routes of adult and juvenile Ipswich sparrows (Passerculus sandwichensis princeps). Movement Ecol 4:1-8. https://doi.org/ 10.1186/s40462-016-0067-8

Darwin C (1874) The descent of man and selection in relation to sex, 2nd edn. John Murray, London

de Zwaan, de Devin R, Wilson S, Gow EA, Martin K (2019) Sex-specific spatiotemporal variation and carry-over effects in a migratory alpine songbird. Front Ecol Evol 7:285. https://doi.org/10.3389/fevo.2019. 00285

Dement'ev GP, Gladkov NA (1954) Birds of the Soviet Union. Sovietskaya Nauka, Moscow

Demongin L (2016) Identification guide to birds in the hand. Cambridge University Press, Cambridge

Deppe JL, Ward MP, Bolus RT, Diehl RH, Celis-Murillo A, Zenzal TJ Jr, Moore FR, Benson TJ, Smolinsky JA, Schofield LN, Enstrom DA, Paxton EH, Bohrer G, Beveroth TA, Raim A, Obringer RL, Delaney D, Cochran WW (2015) Fat, weather, and date affect migratory songbirds' departure decisions, routes, and time it takes to cross the Gulf of Mexico. P Natl Acad Sci USA 112:E6331-E6338

Dingle H (2014) Migration: the biology of life on the move, 2nd edn. Oxford University Press, Oxford

Ellegren H (1990) Autumn migration speed in Scandinavian Bluethroats Luscinia s. svecica. Ringing Migr 11:121-131. https://doi.org/10. 1080/03078698.1990.9673974

Ellegren H (1991) Stopover ecology of autumn migrating Bluethroats Luscinia s. svecica in relation to age and sex. Ornis Scand 22: 340-348. https://doi.org/10.2307/3676506

Francis CM, Cooke F (1986) Differential timing of spring migration in Wood Warblers (Parulinae). Auk 103:548-556. https://doi.org/10. 1093/auk/103.3.548
Gätke H (1879) The migration of birds. Nature 20:97-99. https://doi.org/ $10.1038 / 020097 \mathrm{b0}$

Gauthreaux SA (1978) The ecological significance of behavioral dominance. In: Bateson PPG, Klopfer PH (eds) Social behavior. Springer, Boston, pp 17-54

Gauthreaux SA (1982) The ecology and evolution of avian migration systems. In: Farner DS, King JR, Parkes KC (eds) Avian biology, vol VI. Elsevier Science, Burlington, pp 93-168

Gelman A, Hill J (2016) Data analysis using regression and multilevel hierarchical models. Cambridge University Press, Cambridge

Gill F, Donsker D (2008) IOC world bird names, www.worldbirdnames. org

Gochfeld M, Burger J (1984) Age differences in foraging behavior of the American Robin (Turdus migratorius). Behaviour 88:227-239

Hake M, Kjellén N, Alerstam T (2003) Age-dependent migration strategy in honey buzzards Pernis apivorus tracked by satellite. Oikos 103: 385-396. https://doi.org/10.1034/j.1600-0706.2003.12145.x

Hall-Karlsson KSS, Fransson T (2008) How far do birds fly during one migratory flight stage? Ringing Migr 24:95-100. https://doi.org/10. 1080/03078698.2008.9674381

Heim W, Eccard JA, Bairlein F (2018) Migration phenology determines niche use of East Asian buntings (Emberizidae) during stopover. Curr Zool 64:681-692. https://doi.org/10.1093/cz/zoy016

Heim W, Heim RJ, Beermann I, Burkovskiy OA, Gerasimov Y, Ktitorov P, Ozaki K, Panov I, Sander MM, Sjöberg S, Smirenski SM, Thomas A, Tøttrup AP, Tiunov IM, Willemoes M, Hölzel N, Thorup K, Kamp J (2020) Using geolocator tracking data and ringing archives to validate citizen-science based seasonal predictions of bird distribution in a data-poor region. Global Ecol Conserv 24: e01215. https://doi.org/10.1016/j.gecco.2020.e01215

Heim W, Smirenski SM (2013) The Amur bird project at Muraviovka Park in Far East Russia. BirdingASIA 19:31-33

Heim W, Smirenski SM (2017) The importance of Muraviovka Park, Amur province, Far East Russia, for bird species threatened at regional, national and international level based on observations between 2011 and 2016. Forktail 33:81-87

Heim W, Smirenski SM, Siegmund A, Eidam F (2012) Results of an autumnal bird ringing project at Muraviovka Park (Amur Region) in 2011. Avian Ecol Behav 21:27-40

Hüppop K, Hüppop O (2004) An atlas of bird ringing at the island of Helgoland. Part 2: Phenology in the trapping garden from 1961 to 2000. Vogelwarte 42:285-343

Hüppop O, Hüppop K (2011) Bird migration on Helgoland: the yield from 100 years of research. J Ornithol 152:25-40. https://doi.org/ 10.1007/s10336-011-0705-2

Jenni L, Kéry M (2003) Timing of autumn bird migration under climate change: advances in long-distance migrants, delays in short-distance migrants. Proc R Soc Lond B 270:1467-1471. https://doi.org/10. 1098/rspb.2003.2394

Jones J, Francis CM, Drew M, Fuller S, Ng MWS (2002) Age-related differences in body mass and rates of mass gain of passerines during autumn migratory stopover. Condor 104:49-58. https://doi.org/10. 1093/condor/104.1.49

Kiat Y, Izhaki I (2016) Moult strategies affect age differences in autumn migration timing in East Mediterranean migratory passerines. PLoS One 11:e0147471. https://doi.org/10.1371/journal.pone.0147471

Kiat Y, Izhaki I, Sapir N (2019) The effects of long-distance migration on the evolution of moult strategies in Western-Palearctic passerines. Biol Rev 94:700-720. https://doi.org/10.1111/brv.12474

Kissner KJ, Weatherhead PJ, Francis CM (2003) Sexual size dimorphism and timing of spring migration in birds. J Evol Biol 16:154-162. https://doi.org/10.1046/j.1420-9101.2003.00479.x

Kokko H (1999) Competition for early arrival in migratory birds. J Anim Ecol 68:940-950. https://doi.org/10.1046/j.1365-2656.1999.00343. $\mathrm{x}$ 
Kokko H, Gunnarsson TG, Morrell LJ, Gill JA (2006) Why do female migratory birds arrive later than males? J Anim Ecol 75:1293-1303. https://doi.org/10.1111/j.1365-2656.2006.01151.x

Komar O, O'Shea BJ, Peterson AT, Navarro-Sigüenza AG (2005) Evidence of latitudinal sexual segregation among migratory birds wintering in Mexico. Auk 122:938-948. https://doi.org/10.1093/ auk/122.3.938

Korner-Nievergelt F, Roth T, von Felten S, Guélat J, Almasi B, KornerNievergelt P (2015) Bayesian data analysis in ecology using linear models with R, BUGS, and Stan. Academic Press, Elsevier, Amsterdam

Lecoq M, Catry P (2003) Diurnal tape-luring of wintering Chiffchaffs results in samples with biased sex ratios. J Field Ornithol 74:230 232. https://doi.org/10.1648/0273-8570-74.3.230

Lehikoinen A, Santaharju J, Møller AP (2017) Sex-specific timing of autumn migration in birds: the role of sexual size dimorphism, migration distance and differences in breeding investment. Ornis Fenn 94:53-65

Lok T, Overdijk O, Piersma T (2015) The cost of migration: spoonbills suffer higher mortality during trans-Saharan spring migrations only. Biol Lett 11:20140944. https://doi.org/10.1098/rsbl.2014.0944

Maslovsky KS, Valchuk OP, Leliuchina EV (2018) Differential migration and dynamic of state of the transit population of Siberian rubythroat in southern Primorye: analysis of long-term banding data in the Litovka River valley. Bull Far East Br Russ Acad Sci 2:19-28 [in Russian]

McCabe BJ, Guglielmo CG (2019) Migration takes extra guts for juvenile songbirds: energetics and digestive physiology during the first journey. Front Ecol Evol 7:381. https://doi.org/10.3389/fevo.2019. 00381

McKinnon EA, Fraser KC, Stanley CQ, Stutchbury BJM (2014) Tracking from the tropics reveals behaviour of juvenile songbirds on their first spring migration. PLoS One 9:e105605. https://doi.org/ 10.1371/journal.pone.0105605

Mills AM (2005) Protogyny in autumn migration: do male birds "play chicken"? Auk 122:71-81. https://doi.org/10.1093/auk/122.1.71

Milner-Gulland EJ, Fryxell JM, Sinclair ARE (2011) Animal migration: a synthesis. Oxford University Press, Oxford

Mitchell GW, Newman AEM, Wikelski M, Norris DR (2012) Timing of breeding carries over to influence migratory departure in a songbird: an automated radiotracking study. J Anim Ecol 81:1024-1033. https://doi.org/10.1111/j.1365-2656.2012.01978.x

Mitchell GW, Woodworth BK, Taylor PD, Norris DR (2015) Automated telemetry reveals age specific differences in flight duration and speed are driven by wind conditions in a migratory songbird. Movement Ecol 3:19. https://doi.org/10.1186/s40462-015-0046-5

Moore F, Mabey S, Woodrey MS (2003) Priority access to food in migratory birds: age, sex and motivational asymmetries. In: Berthold $\mathrm{P}$, Gwinner E, Sonnenschein E (eds) Avian migration. Springer, Berlin, pp 281-292

Morbey YE, Ydenberg RC (2001) Protandrous arrival timing to breeding areas: a review. Ecol Lett 4:663-673. https://doi.org/10.1046/j. 1461-0248.2001.00265.x

Müller F, Eikenaar C, Crysler ZJ, Taylor PD, Schmaljohann H (2018) Nocturnal departure timing in songbirds facing distinct migratory challenges. J Anim Ecol 87:1102-1115. https://doi.org/10.1111/ $1365-2656.12821$

Myers JP (1981) A test of three hypotheses for latitudinal segregation of the sexes in wintering birds. Can J Zool 59:1527-1534. https://doi. org/10.1139/z81-207

Nam HY, Choi CY, Park JG, Hong GP, Won IJ, Kim SJ, Bing GC, Chae HY (2011) Protandrous migration and variation in morphological characters in Emberiza buntings at an East Asian stopover site. Ibis 153:494-501. https://doi.org/10.1111/j.1474-919X.2011.01134.x

Neto JM, Encarnação V, Fearon P, Gosler AG (2008) Autumn migration of Savi's Warblers Locustella luscinioides in Portugal: differences in timing, fuel deposition rate and non-stop flight range between the age classes. Bird Study 55:78-85. https://doi.org/10.1080/ 00063650809461507

Newton I (2008) The migration ecology of birds. Elsevier-Academic Press, Amsterdam

R Core Team (2013) R: a language and environment for statistical computing. R Foundation for Statistical Computing, Vienna, Austria www.R-project.org/

Reynolds JD, Colwell MA, Cooke F (1986) Sexual selection and spring arrival times of red-necked and Wilson's phalaropes. Behav Ecol Sociobiol 18:303-310. https://doi.org/10.1007/BF00300008

Rguibi-Idrissi H, Julliard R, Bairlein F (2003) Variation in the stopover duration of Reed Warblers Acrocephalus scirpaceus in Morocco: effects of season, age and site. Ibis 145:650-656. https://doi.org/ 10.1046/j.1474-919X.2003.00208.x

Rubolini D, Spina F, Saino N (2004) Protandry and sexual dimorphism in trans-Saharan migratory birds. Behav Ecol 15:592-601. https://doi. org/10.1093/beheco/arh048

Ruckstuhl KE (2007) Sexual segregation in vertebrates: proximate and ultimate causes. Integr Comp Biol 47:245-257. https://doi.org/10. 1093/icb/icm030

Schekkerman H (1999) Sex bias and seasonal patterns in tape-lured samples of migrating skylarks Alauda arvensis. Ringing Migr 19:299 305. https://doi.org/10.1080/03078698.1999.9674196

Schmaljohann H (2019) The start of migration correlates with arrival timing, and the total speed of migration increases with migration distance in migratory songbirds: a cross-continental analysis. Movement Ecol 7:1-18. https://doi.org/10.1186/s40462-019-01691

Schmaljohann H, Meier C, Arlt D, Bairlein F, van Oosten H, Morbey YE, Åkesson S, Buchmann M, Chernetsov N, Desaever R, Elliott J, Hellström M, Liechti F, López A, Middleton J, Ottosson U, Pärt T, Spina F, Eikenaar C (2016) Proximate causes of avian protandry differ between subspecies with contrasting migration challenges. Behav Ecol 2(7):321-331. https://doi.org/10.1093/beheco/arv160

Schmaljohann H, Müller F, Klinner T, Eikenaar C (2018) Potential age differences in the migratory behaviour of a nocturnal songbird migrant during autumn and spring. J Avian Biol 49:e01815. https://doi. org/10.1111/jav.01815

Seewagen CL, Guglielmo CG, Morbey YE (2013) Stopover refueling rate underlies protandry and seasonal variation in migration timing of songbirds. Behav Ecol 24:634-642. https://doi.org/10.1093/ beheco/ars 225

Sergio F, Tanferna A, de Stephanis R, Jiménez LL, Blas J, Tavecchia G, Preatoni D, Hiraldo F (2014) Individual improvements and selective mortality shape lifelong migratory performance. Nature 515:410 413. https://doi.org/10.1038/nature13696

Shirihai H, Svensson L (2018) Handbook of Western Palearctic birds. Bloomsbury Publishing, London

Smetzer JR, King DI, Taylor PD (2017) Fall migratory departure decisions and routes of blackpoll warblers Setophaga striata and redeyed vireos Vireo olivaceus at a coastal barrier in the Gulf of Maine. J Avian Biol 48:1451-1461. https://doi.org/10.1111/jav.01450

Smolinsky JA, Diehl RH, Radzio TA, Delaney DK, Moore FR (2013) Factors influencing the movement biology of migrant songbirds confronted with an ecological barrier. Behav Ecol Sociobiol 67: 2041-2051. https://doi.org/10.1007/s00265-013-1614-6

Spina F, Massi A, Montemaggiori A (1994) Back from Africa: who's running ahead? Aspects of differential migration of sex and age classes in Palearctic-African spring migrants. Ostrich 65:137-150. https://doi.org/10.1080/00306525.1994.9639676

Stewart RLM, Francis CM, Massey C (2002) Age-related differential timing of spring migration within sexes in passerines. Wilson Bull $114: 264-271$

Svensson L (1992) Identification guide to european passerines, 4th revised and, enlarged edn. Published by the author, Stockholm 
Thorup K, Tøttrup AP, Willemoes M, Klaassen RHG, Strandberg R, Vega ML, Dasari HP, Araújo MB, Wikelski M, Rahbek C (2017) Resource tracking within and across continents in long-distance bird migrants. Sci Adv 3:e1601360. https://doi.org/10.1126/sciadv. 1601360

Tøttrup AP, Thorup K (2008) Sex-differentiated migration patterns, protandry and phenology in North European songbird populations. J Ornithol 149:161-167. https://doi.org/10.1007/s10336-007-0254$\mathrm{x}$

Valchuk OP (2003) Interruption of autumn migration for molt in a Palaearctic passerine: the chestnut bunting Emberiza rutila case. Vogelwarte 42:23

van Buskirk J, Mulvihill RS, Lebermann RC (2009) Variable shifts in spring and autumn migration phenology in North American songbirds associated with climate change. Glob Change Biol 15:760771. https://doi.org/10.1111/j.1365-2486.2008.01751.x

van de Pol M, Verhulst S (2006) Age-dependent traits: a new statistical model to separate within- and between-individual effects. Am Nat 167:766-773. https://doi.org/10.1086/503331

Wang Y, Chang J, Moore FR, Su L, Cui L, Yang X (2006) Stopover ecology of Red-flanked Bush Robin (Tarsiger cyanurus) at Maoershan, Northeast China. Acta Ecol Sin 26:638-646. https:// doi.org/10.1016/S1872-2032(06)60011-5
Woodrey MS, Chandler CR (1997) Age-related timing of migration: geographic and interspecific patterns. Wilson Bull 109:52-67

Woodworth BK, Newman AEM, Turbek SP, Dossman BC, Hobson KA, Wassenaar LI, Mitchell GW, Wheelwright NT, Norris DR (2016) Differential migration and the link between winter latitude, timing of migration, and breeding in a songbird. Oecologia 181:413-422. https://doi.org/10.1007/s00442-015-3527-8

Wunderle J (1991) Age-specific foraging proficiency in birds. Curr Ornithol 8:273-324

Yosef R, Wineman A (2010) Differential stopover of blackcap (Sylvia atricapilla) by sex and age at Eilat, Israel. J Arid Environ 74:360 367. https://doi.org/10.1016/j.jaridenv.2009.09.004

Zhang H, Vedder O, Becker PH, Bouwhuis S (2015a) Age-dependent trait variation: the relative contribution of within-individual change, selective appearance and disappearance in a long-lived seabird. J Anim Ecol 84:797-807. https://doi.org/10.1111/1365-2656.12321

Zhang H, Vedder O, Becker PH, Bouwhuis S (2015b) Contrasting between- and within-individual trait effects on mortality risk in a long-lived seabird. Ecology 96:71-79. https://doi.org/10.1890/140064.1

Publisher's note Springer Nature remains neutral with regard to jurisdictional claims in published maps and institutional affiliations. 